Original paper

\title{
Expulsion of zooxanthellae (Symbiodinium) from several species of scleractinian corals: comparison under non-stress conditions and thermal stress conditions
}

\author{
Lisa FUJISE ${ }^{1}$, Hiroshi YAMASHITA ${ }^{2}$, Go SUZUKI ${ }^{2}$, and Kazuhiko KOIKE ${ }^{1, *}$ \\ ${ }^{1}$ Graduate School of Biosphere Science, Hiroshima University, 1-4-4 Kagamiyama, Higashi-Hiroshima, Hiroshima 739- \\ 8528, Japan \\ ${ }^{2}$ Research Center for Subtropical Fisheries, Seikai National Fisheries Research Institute, Fisheries Research Agency, \\ 148-446 Fukai-Ohta, Ishigaki, Okinawa 907-0451, Japan \\ * Corresponding author: K. Koike \\ E-mail: kazkoike@hiroshima-u.ac.jp \\ Communicated by Michio Hidaka (Editorial Board Member)
}

\begin{abstract}
Corals expel zooxanthellae (Symbiodinium) not only under thermal stress conditions, but also under nonstress conditions. To better understand the significance of this, we compared cell numbers, morphologies and photosynthetic activities of the expelled Symbiodinium under different temperatures for six species of scleractinian corals; Acropora selago, Acropora muricata, Heliofungia actiniformis, Ctenactis echinata, Oxypora lacera and Pocillopora eydouxi, kept in aquariua. During the eight day aquarium experiment, every coral expelled two types of Symbiodinium morphologies, normal and degraded form, and the ratios of these forms differed depending on the temperature. Under a non-stress, initial temperature condition of $27^{\circ} \mathrm{C}$, mainly degraded cells were expelled. In contrast, when the water temperature was increased and reached to $32^{\circ} \mathrm{C}$, the expulsion rates drastically increased, except $P$. eydouxi, and almost all the expelled populations exhibited normal cell morphology. Under this thermal stress conditions, photosystem II maximum quantum yield $(F v / F m)$ of expelled Symbiodinium from two Acroporidae and two Fungiidae was 35\% lower than those retained in the tissue, but was not significantly different in the cases of $O$. lacera and $P$. eydouxi. These results in-
\end{abstract}

dicate that, under the non-stress conditions, the corals functionally regulate Symbiodinium density by expelling degraded cells. This function may collapse under hightemperature stress, resulting in the extensive loss of healthy-looking but photosynthetically damaged Symbiodinium, probably because of host cell detachment. Moreover, susceptibilities toward temperature increase might be different in coral species or symbiont types and result in the differences of expulsion amounts or photosynthesis damages.

Keywords Symbiodinium, Degraded cell, Expulsion mechanism, Coral bleaching

\section{Introduction}

Corals and some other marine invertebrates form symbioses with unicellular microalgae called zooxanthellae (dinoflagellate genus Symbiodinium). Symbiodinium inhabit coral tissues and provide photosynthetic products necessary for corals to survive in oligotrophic tropical 
waters (e.g. Muscatine 1967; Muscatine and Cernichiari 1969). Under stressful conditions, the relationship can collapse, causing corals to expel large amounts of Symbiodinium and often resulting in "coral bleaching" (Goreau 1964; Jaap 1979; Egaña and DiSalvo 1982; HoeghGuldberg and Smith 1989; Gates et al. 1992; Brown et al. 1995; Brown 1997). Corals can also expel Symbiodinium under non-stressful conditions (Hoegh-Guldberg et al. 1987; Titlyanov et al. 1996; 1998; Jones and Yellowlees 1997; Baghdasarian and Muscatine 2000; Koike et al. 2007; Dimond and Carrington 2008; Yamashita et al. 2011). These "expulsion" phenomena do not share the same mechanism: the former instance seems to be a breakdown of the Symbiodinium maintenance system in corals, while the latter case is the steady-state healthy function in corals. In the reports dealing with Symbiodinium expulsion under stressful conditions, there were seemingly healthy cells in the expelled populations (e.g. Gates et al. 1992; Ralph et al. 2001; Bhagooli and Hidaka 2004; Ralph et al. 2005; Hill and Ralph 2007), which would reduce photosynthetic capacities in corals-symbionts relationship. Titlyanov et al. $(1996 ; 1998)$ reported corals under non-stress conditions actively expelled "degraded" Symbiodinium cells from the polyp mouth and concluded that the mechanism is to regulate Symbiodinium density in the corals. Understanding these functional differences between different types of expulsion would lead to a better understanding of Symbiodinium losses in corals. There are few studies focusing on the expulsion of degraded cells under non-stress conditions contrasted with the expulsion of healthy-looking cells under stressful conditions and quantitatively comparing these cells for a variety of corals.

In this study, we compared the abundance of degraded cells and healthy-looking Symbiodinium cells in the expelled materials from six species of scleractinian corals in aquaria, under non-stress $\left(27^{\circ} \mathrm{C}\right)$ and stressful conditions $\left(32^{\circ} \mathrm{C}\right)$, to understand the maintenance and collapse of symbiosis between corals and Symbiodinium.

\section{Materials and methods}

\section{Collection of corals and aquarium conditions}

In October 2011, six species of scleractinian corals were collected at the Urasoko Bay, Ishigaki Island, Okinawa, Japan $\left(24^{\circ} 27^{\prime} \mathrm{N}, 124^{\circ} 13^{\prime} \mathrm{E}\right)$. These were Acropora selago (Studer, 1878) (collected $1 \mathrm{~m}$ depth, $594 \mathrm{~g}$ of total skeletal weight), Acropora muricata (Linnaeus, 1758) (2 m, $383 \mathrm{~g}$ ), Heliofungia actiniformis (Quoy and Gaimard, 1833) (19 m, 1,012 g), Ctenactis echinata (Pallas, 1766) (18 m, 1,003 g), Oxypora lacera (Verrill, 1864) (24 m, $268 \mathrm{~g}$ ), and Pocillopora eydouxi (Edwards and Haime, 1860) ( $7 \mathrm{~m}, 1,080 \mathrm{~g})$. A. selago and A. muricata were selected as representatives of bleaching sensitive species in Acroporidae, and H. actiniformis and C. echinata were in Fungiidae. O. lacera and P. eydouxi were representatives of a deep-water species and a bleaching tolerant species, respectively. We should note that the aim of this study was to cover expulsion trends in wide species ranges from bleaching sensitive to insensitive and thus the experiment was not employed in multipilcate, rather one or two colonies for each coral species (total skeletal weights were mentioned above) were put into a single $12 \mathrm{~L}$ aquarium by species. These six $12 \mathrm{~L}$ aquaria were situated in a large water bath to maintain the water temperature at $27^{\circ} \mathrm{C}$. The aquaria were aerated with air-stones and maintained with temperature-regulated flowing seawater (provided by a GA7500-ODHT-E, Gunji, Osaka, Japan) filtered by MEMCOR Ultra-filtration unit $(0.2 \mu \mathrm{m}$ pore size membrane module, JFE Engineering, Tokyo, Japan) at a flow-rate of $1 \mathrm{~L} \mathrm{~min}{ }^{-1}$ for each aquarium. The light was provided by three $500 \mathrm{~W}$ metal halide lamps and six $12 \mathrm{~W}$ LED lights, hanging over the entire aquaria, at a photonflux density of $220 \mu \mathrm{mol}$ photons $\mathrm{m}^{-2} \mathrm{~s}^{-1}$ with a $12: 12 \mathrm{~h}$ light/dark cycle. The experiment was performed at the Research Center for Subtropical Fisheries, Seikai National Fisheries Research Institute, in Okinawa, Japan.

\section{Temperature treatments}

After a two-week period of acclimation, the experiment was started as follows: for the first two days, temperature was maintained at $27^{\circ} \mathrm{C}$. The seawater temperature was raised stepwise $\left(0.5^{\circ} \mathrm{C}\right.$ increase for every $\left.8 \mathrm{~h}\right)$ for the following three days, until it reached $32^{\circ} \mathrm{C}$, where it was maintained for three days.

\section{Collection of expelled Symbiodinium from the corals}

Expelled Symbiodinium from the corals were collected 
in the initial two days at $27^{\circ} \mathrm{C}$ and in the three days at $32^{\circ} \mathrm{C}$. To determine expulsion during the temperature increase, samples were also collected for two more days after the initial two days for $A$. selago and $H$. actiniformis. According to our previous report (Koike et al. 2007), corals have a daily rhythmicity of Symbiodinium expulsion, with a peak at noon. Therefore, from 12:00 to 14:00, the supplies of seawater to the aquaria were stopped, and expelled Symbiodinium during these two hours accumulated in the aquaria. To prevent the water temperature from increasing, the seawater was kept running into the water bath. Four L of seawater (including expelled Symbiodinium) in each aquarium was collected after mixing it well and sieved through a $20-\mu \mathrm{m}$ mesh to remove large particles, then concentrated into $50 \mathrm{ml}$ using a $5-\mu \mathrm{m}$ mesh. Microscopy confirmed absence of Symbiodinium in the filtrate.

\section{Counting the expelled Symbiodinium}

Symbiodinium cells in $1 \mathrm{ml}$ of the concentrated sample were trapped onto a polycarbonate filter (Isopore membrane filters, $0.8 \mu \mathrm{m}$ ATTP, ATTP01300, Millipore, Billerica, MA, USA) by gentle vacuuming. The filter was then put onto a slide glass, immersed in a drop of mineral oil to prevent dehydration and oxidation, and covered with a cover slip. Samples were kept in the dark and stored in a freezer $\left(-20^{\circ} \mathrm{C}\right)$ until observation. The cells on the filter were counted by observing chlorophyll $a$ auto-fluorescence under an epi-fluorescent microscope (BX51, Olympus,
Tokyo, Japan) with blue light excitation. Fluorescence and transmitted-light micrographs were taken of twenty randomly selected areas using a microscopy camera (Cool Snap ES, Photometrics, Tucson, AZ, USA) under a $20 \times$ objective lens. The cell numbers of Symbiodinium were counted by the morphologies in the micrographs: a normal form in which the size was around $10 \mu \mathrm{m}$ and possessed bright auto-fluorescence, and a degraded form around half the normal form size with a weak auto-fluorescence and a condensed form (Fig. 1). The cell numbers per each observation field were averaged for the twenty areas, and total cell numbers were determined per $1 \mathrm{ml}$ of concentrated sample. Expelled Symbiodinium cell numbers per an aquarium were determined and converted to hourly expelled cells per $100 \mathrm{~g}$ of coral skeletal weight.

\section{Measurement of PSII maximum quantum yield of Sym- biodinium}

A dark-adapted maximum quantum yield of photosystem II $(F v / F m)$ was measured using a pulse-amplitude modulation (PAM) fluorometer (WATER-PAM, Walz, Effeltrich, Germany) (PM gain 10) for both expelled Symbiodinium and freshly isolated Symbiodinium from the host tissue. The latter Symbiodinium were obtained using a water-pik, and the concentrated samples of expelled Symbiodinium were used for this measurement. The measurements were conducted every day; however, the fluorescence during the initial two days was too low to determine $\mathrm{Fv} / \mathrm{Fm}$ and was therefore removed from the data.
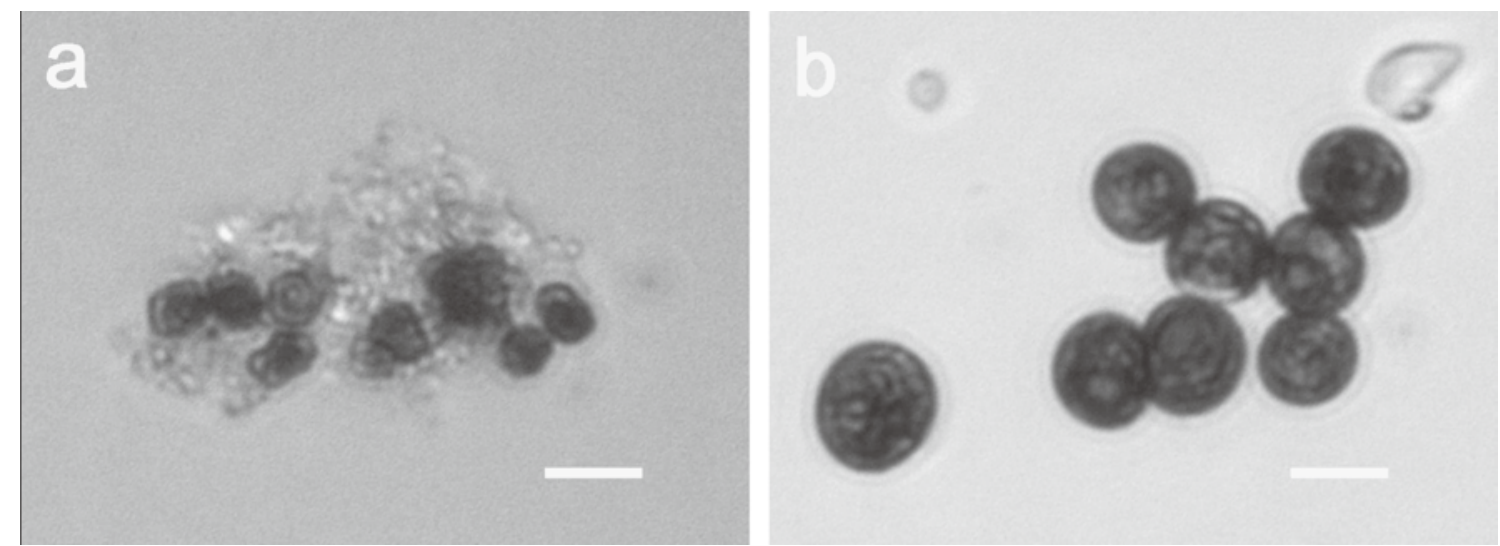

Fig. 1 Micrographs of Symbiodinium cells expelled from corals. a Micrograph of degraded forms of Symbiodinium expelled under non-stress conditions. b Micrograph of normal forms of Symbiodinium expelled under thermal stress conditions. Scale bars are $10 \mu \mathrm{m}$ 
During the third day after reaching $32^{\circ} \mathrm{C}$, diatoms increased in the aquaria and the data obtained from these waters were also rejected.

\section{Results}

\section{Numbers of expelled Symbiodinium from corals}

Fig. 2 shows the numbers of expelled Symbiodinium cells from the corals (hourly expulsion per $100 \mathrm{~g}$ of coral skeletal weight) grouped by morphologies: normal and degraded forms (Fig. 1). Total number of expulsions drastically increased under the thermal stress conditions compared with those under the non-stress conditions, except for $P$. eydouxi. The numbers of expelled Symbiodinium cells after reaching $32^{\circ} \mathrm{C}$ (average for the three days at the temperature) were higher than the average for the initial two days at $27^{\circ} \mathrm{C}$, for $A$. muricata (4 times), A. selago (34 times), H. actiniformis (7 times), C. echinata (7 times), and $O$. lacera (39 times). $P$. eydouxi expelled almost the same amount during the non-stress and the thermal stress conditions, and the values were one or two orders lower than the remaining five species.

\section{Morphologies of expelled Symbiodinium from corals}

All six corals expelled more degraded forms under the non-stress conditions and more normal forms under the thermal stress conditions (Fig. 2 and 3). The average ratios of the degraded forms under the non-stress conditions (for the initial two days) were 60, 56, 41, 58, 41 and 85\% for A. muricata, A. selago, $H$. actiniformis, C. echinata, $O$. lacera and P. eydouxi, respectively. Under the thermal stress conditions, however, the average ratios for three days at $32^{\circ} \mathrm{C}$ were $8,7,1,0,0$ and $5 \%$, respectively. This indicates that the remaining 92 to $100 \%$ of the Symbiodinium biomass was composed of the normal form under the thermal stress conditions. The expulsion under the non-stress conditions was mainly due to the relatively small numbers of degraded Symbiodinium, while under the thermal stress conditions, the expulsion was composed of a large number of normal Symbiodinium and few degraded Symbiodinium form.

\section{PSII maximum quantum yield $(\mathrm{Fv} / \mathrm{Fm})$ of freshly iso- lated Symbiodinium and expelled Symbiodinium from corals}

Fig. 4 shows $F v / F m$ values of freshly isolated Symbio-
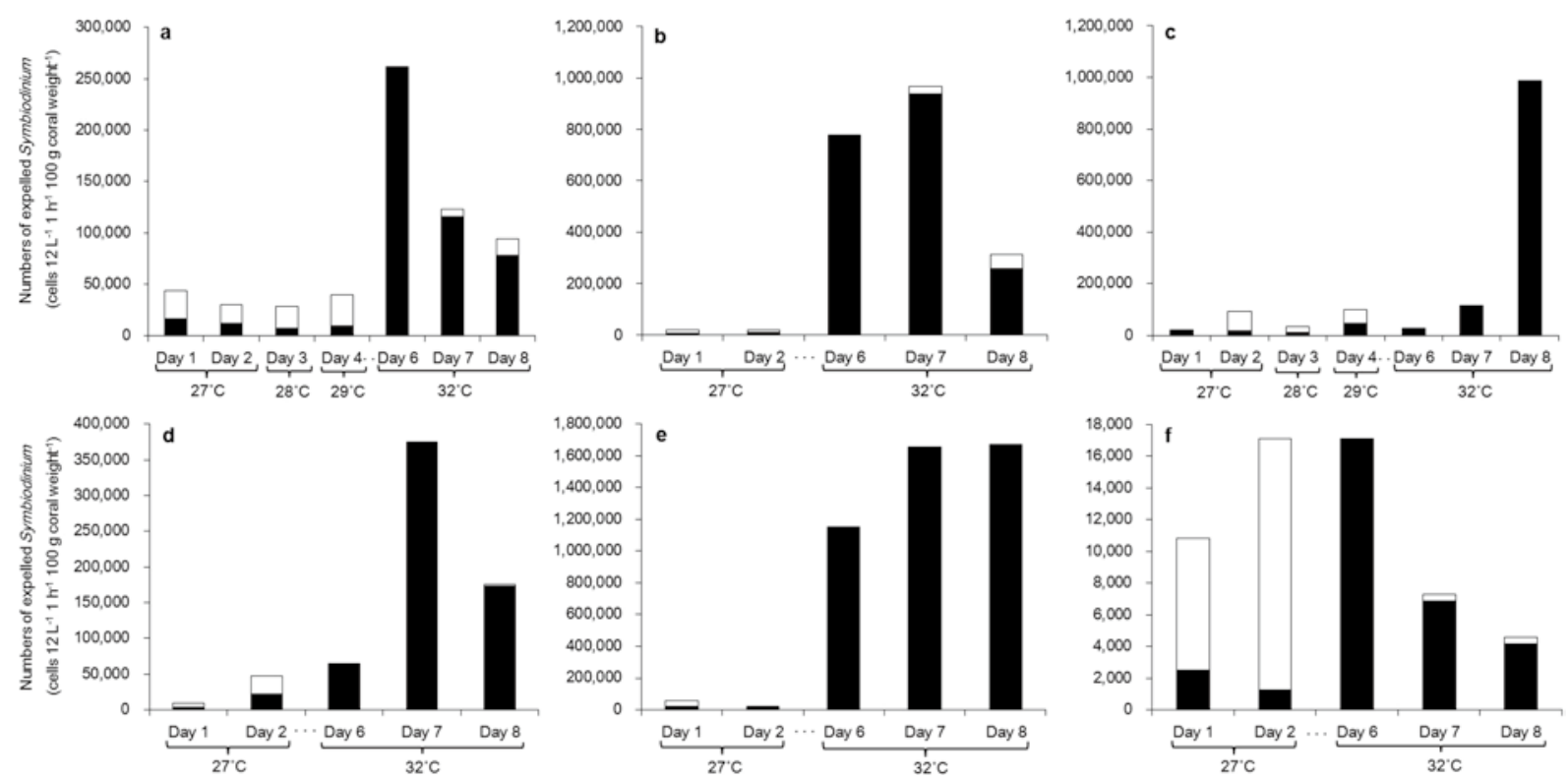

Fig. 2 Cell numbers of expelled Symbiodinium from corals. The black bar graph shows the number of normal forms of Symbiodinium and the white bar graph shows the number of degraded forms of Symbiodinium. The scales of cell numbers are different in each coral. a A. selago. b A. muricata. c H. actiniformis. d C. echinata. e O. lacera. f P. eydouxi 

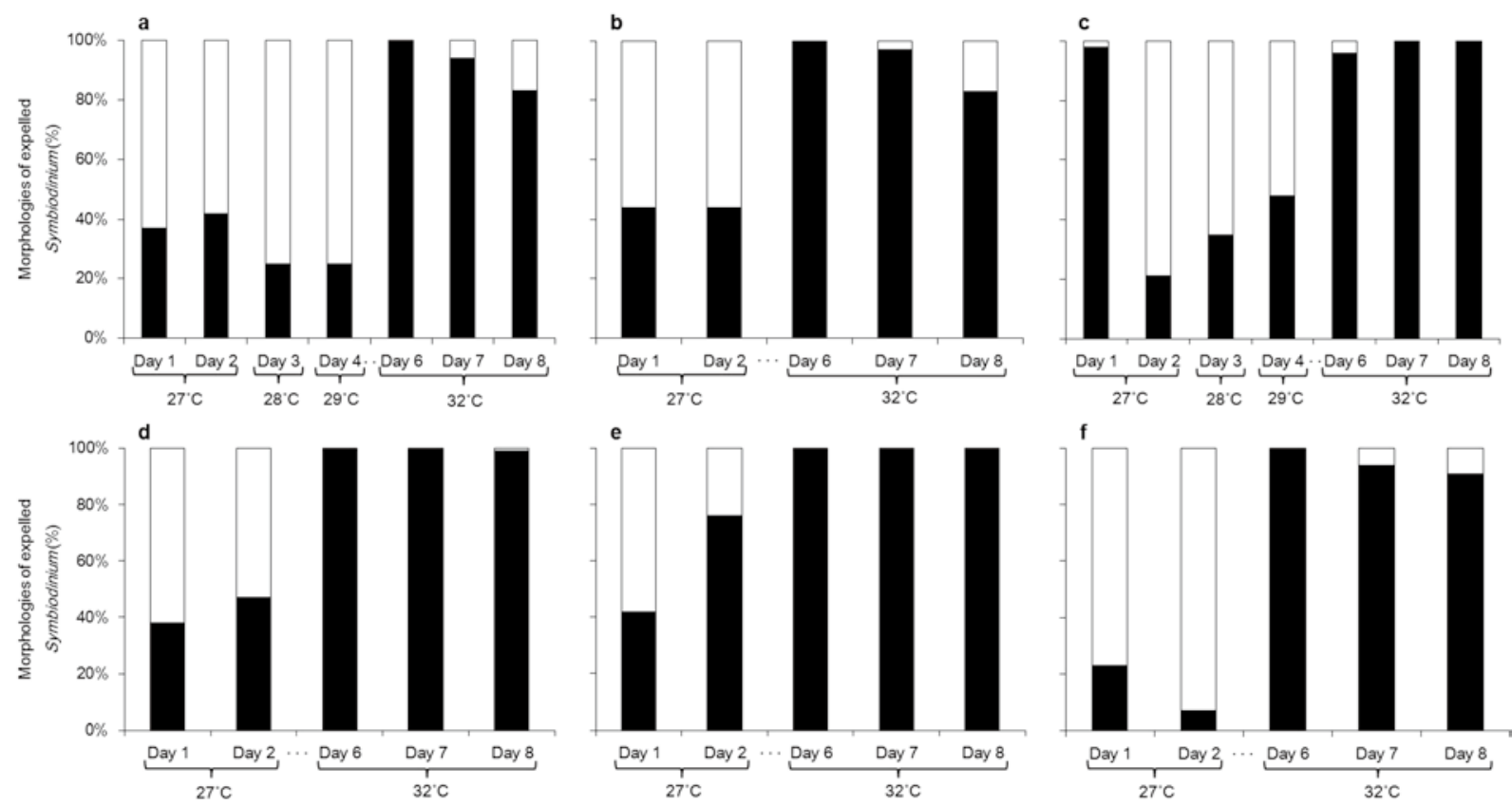

Fig. 3 Ratio of morphologies of expelled Symbiodinium from corals. The black bar graph shows the percentage of normal forms of Symbiodinium and the white bar graph shows the percentage of degraded forms of Symbiodinium. a A. selago. b A. muricata. c H. actiniformis. d C. echinata. e O. lacera. f P. eydouxi
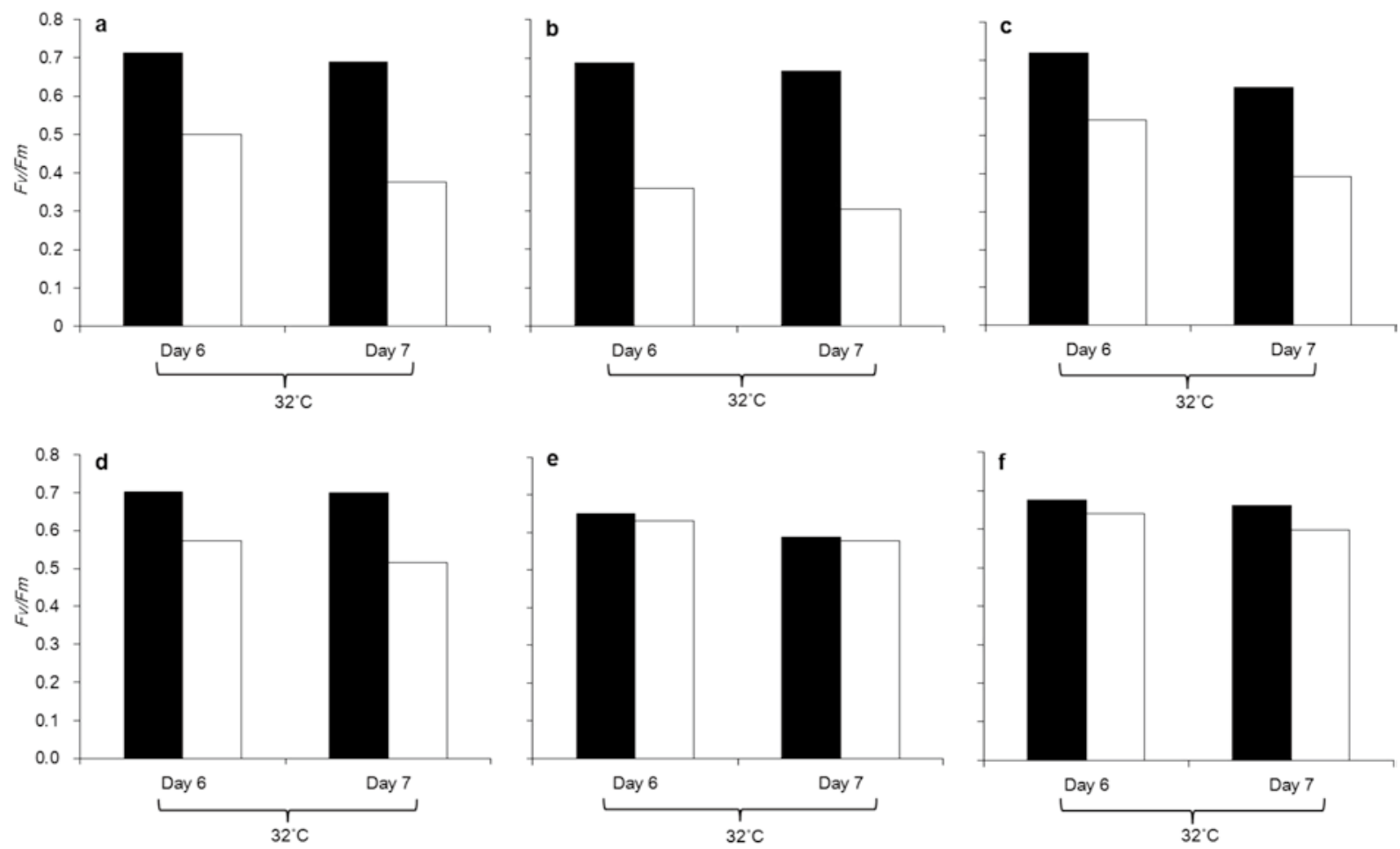

Fig. $4 \mathrm{Fv} / \mathrm{Fm}$ of freshly isolated Symbiodinium (black bar) and expelled Symbiodinium from corals (white bar) under thermal stress conditions. a A. selago. b A. muricata. c H. actiniformis. d C. echinata. e O. lacera. f $P$. eydouxi 
dinium (black bars) and of the expelled cells (white bars). Even under the thermal stress conditions, the values of freshly isolated Symbiodinium were high: on the initial day after reaching $32^{\circ} \mathrm{C}$, they were greater than 0.65 , and on the second day were still as high as 0.63 , except in $O$. lacera (0.59). This implies that the Symbiodinium resident in the coral tissue were slightly damaged under the high temperature but were still photosynthetically competent. In contrast, regardless of the healthy-looking natures of the expelled Symbiodinium, $F v / F m$ values of the expelled Symbiodinium were lower than those in the coral tissue. Two Acroporidae and two Fungiidae were 0.45 on average for two days and $35 \%$ lower than in the tissue. Interestingly, the expelled cells from $O$. lacera and $P$. eydouxi did not exhibit such significant drops in $F v / F m$, and still maintained competent values of 0.60 and 0.62 for two days.

\section{Discussion}

These six corals expelled more degraded Symbiodinium cells under the non-stress steady conditions and more healthy-looking, but photosynthetically damaged cells, (especially in Acroporidae and Fungiidae) under the thermal stress conditions. The expulsion under the non-stress conditions is considered to be a functional mechanism to regulate Symbiodinium density within corals. Such a mechanism has been proposed by previous studies in many coral species (Titlyanov et al. 1996, 1998; Jones and Yellowlees 1997; Baghdasarian and Muscatine 2000; Dimond and Carrington 2008). Titlyanov et al. (1996; 1998) reported that the number of degraded Symbiodinium in corals was similar to the number of dividing Symbiodini$u m$, concluding that the digestion and expulsion of Symbiodinium might be a functional regulation for Symbiodinium densities in corals. Our current results agreed with these findings, and we can conclude that the expulsion of degraded (digested) cells is a mechanism for corals to regulate the symbionts. In contrast, under the thermal stress conditions, large numbers of the normal form Symbiodinium were expelled from the corals, and the phenomenon apparently results in coral discoloration. Under these circumstances, few degraded Symbiodinium were expelled in contrast to the report by Downs et al. (2009) in which the digestion of Symbiodinium in the coral tissue was promoted by heat stress. In another study, degraded Symbiodinium accumulated in coral tissues in naturally bleached corals (Brown et al. 1995). Consequently, under such stress conditions, digestion of Symbiodinium may occur, but disposal from the polyp mouth (Titlyanov et al. 1996; 1998) is disabled and results in the accumulation of waste cells. Compared with such an active dumping mechanism, expulsion under thermal stress conditions seems to be a negative action for corals, probably because of host cell detachment, as observed by Gates et al. (1992). Even though such cell detachment occurs, degraded Symbiodinium would not be expelled at the early stage of the stressful conditions since they mainly inhabit mesenterial filaments (Brown et al. 1995; Titlyanov et al. 1996), which are probably not influenced by host cell detachment. However, when corals are exposed to thermal stress conditions over a longer time, degraded Symbiodinium might increase (Brown et al. 1995), and be eventually expelled as reported by Franklin et al. (2004), in which they observed only degraded Symbiodinium were expelled from Stylophora pistillata exposed to harsh thermal and light conditions.

Two Acroporidae (A. muricata and A. selago) and Fungiidae species (H. actiniformis and C. echinata) expelled Symbiodinium that were more photosynthetically damaged than those that resided in the tissue. If the expulsion under thermal stress conditions is indeed caused by host cell detachment, such "selective" releases for damaged cells are not feasible. Alternatively, we considered that Symbiodinium inhabiting the outer layer of the endodermal tissues adjacent to environment were more subjected to environment stresses. On the other hand, those in the inner layer of the endoderm across the gastrovascular cavity and facing the coral skeleton were less affected (inner layer and outer layer of endoderm were showed in diagrams of Brown et al. 1995 and Titlyanov et al. 1996 studies). More damaged Symbiodinium were present in the outer layer, and therefore expelled Symbiodinium due to host cell detachment might result in the expulsion of photosynthetically damaged cells, while the cells extracted by the water-pik were also derived from the inner layer of the endoderm and thus gave higher $F v / F m$ values. Interestingly, O. lacera and $P$. eydouxi expelled Symbiodinium having almost the same 
competency as the freshly isolated cells. Bhagooli and Hidaka (2004), Ralph et al. (2001; 2005) and Hill and Ralph (2007) reported that photosynthetically active Symbiodinium could be expelled from Galaxea fascicularis, Cyphastrea serailia and Pocillopora damicornis even under high water temperatures. These reports are congruent with our results from O. lacera and P. eydouxi. Nevertheless, we assume that the consequences of the Symbiodinium expulsion are different between these two species because the numbers of expelled Symbiodinium were different. $O$. lacera is a rather deep-water species and seems to be less tolerant of increased temperature. O. lacera expelled extremely large numbers of Symbiodinium under the thermal stress conditions with many cnidocysts, indicating that extensive host cell detachment, probably with the inner parts of coral tissue, might occur. On the contrary, the numbers of expelled Symbiodinium from P. eydouxi were not different between the non-stress and thermal stress conditions. P. eydouxi has been reported to be a thermal tolerant species (Baird and Marshall 1998; Paulay and Benayahu 1999), probably because of a relationship with clade D Symbiodinium, which is a thermally tolerable genotype (Glynn et al. 2001; Rowan 2004). P. eydouxi in the study area Urasoko Bay, also harbored clade D Symbiodinium (Yamashita et al. 2011). From these results, it is assumed that $P$. eydouxi expelled photosynthetically competent Symbiodinium, but in small numbers.

In conclusion, the expulsion mechanisms for corals are divided into two types. One is a regulation mechanism for corals to maintain constant Symbiodinium density. In this mechanism, they digest excess Symbiodinium and expel the degraded cells. This is a normal function for corals to maintain symbionts. However, when this function collapses under thermal stress, interaction between corals and Symbiodinium breaks down, and corals lose a large number of "healthy-looking" Symbiodinium through host cell detachment, which may result in "coral bleaching". Expulsion is a key mechanism for maintenance and collapse of symbiosis between corals and Symbiodinium.

The study was conducted only for a single batch for each species, and thus the results are still preliminary. However, trends of expulsion patterns were common among the coral species, in which expulsion under the non-stress conditions was mainly due to the relatively small numbers of degraded Symbiodinium, while under the thermal stress conditions, the expulsion was composed of a large number of normal cells. The strength of reactions, however, differed between the coral species, and quantitative experiments and statistical analysis will be needed in replicate experiments, including subjecting other stress factors than merely temperature stress. Moreover, observing expulsion patterns in wild corals in the field is necessary to elucidate whether the trends that we found in this study also happen in nature.

\section{Acknowledgments}

This work was supported by a Grant-in-Aid (No. 24570028) for Scientific Research from the Ministry of Education, Culture, Sports, Science and Technology of Japan to KK. The authors express their sincere thanks to the Research Center for Subtropical Fisheries, Seikai National Fisheries Research Institute, Fisheries Research Agency for support during this investigation.

\section{References}

Baghdasarian G, Muscatine L (2000) Preferential expulsion of dividing algal cells as a mechanism for regulating algalcnidarian symbiosis. Biol Bull 199: 278-286

Baird AH, Marshall PA (1998) Mass bleaching of corals on the Great Barrier Reef. Coral Reefs 17: 376

Bhagooli R, Hidaka M (2004) Release of zooxanthellae with intact photosynthetic activity by the coral Galaxea fascicularis in response to high temperature stress. Mar Biol 145: 329-337

Brown BE (1997) Coral bleaching: causes and consequences. Coral Reefs 16: S129-S138

Brown BE, Le Tissier MDA, Bythell JC (1995) Mechanisms of bleaching deduced from histological studies of reef corals sampled during a natural bleaching event. Mar Biol 122: 655-663

Dimond J, Carrington E (2008) Symbiosis regulation in a facultatively symbiotic temperate coral: zooxanthellae division and expulsion. Coral Reefs 27: 601-604

Downs CA, Kramarsky-Winter E, Martinez J, Kushmaro A, Woodley CM, Loya Y, Ostrander GK (2009) Symbiophagy 
as a cellular mechanism for coral bleaching. Autophagy 5:

211-216

Egaña AC, DiSalvo LH (1982) Mass expulsion of zooxanthellae by Easter Island corals. Pac Sci 36: 61-63

Franklin DJ, Hoegh-Guldberg P, Jones RJ, Berges JA (2004) Cell death and degeneration in the symbiotic dinoflagellates of the coral Stylophora pistillata during bleaching. Mar Ecol Prog Ser 272: 117-130

Gates RD, Baghdasarian G, Muscatine L (1992) Temperature stress causes host cell detachment in symbiotic cnidarians: implications for coral bleaching. Biol Bull 182: 324-332

Glynn PW, Maté JL, Baker AC, Calderón MO (2001) Coral bleaching and mortality in Panama and Ecuador during the 1997-1998 El Niño-Southern Oscillation event: spatial/ temporal patterns and comparisons with the 1982-1983 event. Bull Mar Sci 69: 79-109

Goreau TF (1964) Mass expulsion of zooxanthellae from Jamaican reef communities after hurricane Flora. Science 145: 383-386

Hill R, Ralph PJ (2007) Post-bleaching viability of expelled zooxanthellae from the scleractinian coral Pocillopora damicornis. Mar Ecol Prog Ser 352: 137-144

Hoegh-Guldberg O, McCloskey LR, Muscatine L (1987) Expulsion of zooxanthellae by symbiotic cnidarians from the Red Sea. Coral Reefs 5: 201-204

Hoegh-Guldberg O, Smith GJ (1989) The effect of sudden changes in temperature, light and salinity on the population density and export of zooxanthellae from the reef corals Stylophora pistillata Esper and Seriatopora hystrix Dana. J Exp Mar Biol Ecol 129: 279-303

Jaap WC (1979) Observations on zooxanthellae expulsion at Middle Sambo Reef, Florida Keys. Bull Mar Sci 29: 412422

Jones RJ, Yellowlees D (1997) Regulation and control of intracellular algae $(=$ zooxanthellae $)$ in hard corals. Phil Trans R Soc Lond B 352: 457-468
Koike K, Yamashita H, Oh-Uchi A, Tamaki M, Hayashibara T (2007) A quantitative real-time PCR method for monitoring Symbiodinium in the water colum. Galaxea 9: 1-12

Muscatine L (1967) Glycerol excretion by symbiotic algae from corals and Tridacna and its control by the host. Science 156: 516-519

Muscatine L, Cernichiari E(1969) Assimilation of photosynthetic products of zooxanthellae by a reef coral. Biol Bull 137: 506-523

Paulay G, Benayahu Y (1999) Patterns and consequences of coral bleaching in Micronesia (Majuro and Guam) in 1992-1994. Micronesica 31: 109-124

Ralph PJ, Gademann R, Larkum AWD (2001) Zooxanthellae expelled from bleached corals at $33^{\circ} \mathrm{C}$ are photosynthetically competent. Mar Ecol Prog Ser 220: 163-168

Ralph PJ, Larkum AWD, Kühl M (2005) Temporal patterns in effective quantum yield of individual zooxanthellae expelled during bleaching. J Exp Mar Biol Ecol 316: 17-28

Rowan R (2004) Thermal adaptation in reef coral symbionts. Nature 430: 742

Titlyanov EA, Titlyanova TV, Leletkin VA, Tsukahara J, van Woesik R, Yamazato K (1996) Degradation of zooxanthellae and regulation of their density in hermatypic corals. Mar Ecol Prog Ser 139: 167-178

Titlyanov EA, Titlyanova TV, Loya Y, Yamazato K (1998) Degradation and proliferation of zooxanthellae in planulae of the hematypic coral Stylophora pistillata. Mar Biol 130: 471-477

Yamashita H, Suzuki G, Hayashibara T, Koike K (2011) Do corals select zooxanthellae by alternative discharge? Mar Biol 158: 87-100

Received: 3 June 2013

Accepted: 27 July 2013

(C) Japanese Coral Reef Society 